\title{
Sea-spray deposition in Antarctic coastal and plateau areas from ITASE traverses
}

\author{
Silvia BENASSAI, ${ }^{1}$ Silvia BECAGLI, ${ }^{1}$ Roberto GRAGNANI, ${ }^{2}$ Olivier MAGAND, ${ }^{3}$ \\ Marco PROPOSITO, ${ }^{2}$ Ilaria FATTORI, ${ }^{1}$ Rita TRAVERSI, ${ }^{1}$ Roberto UDISTI ${ }^{1}$ \\ ${ }^{1}$ Department of Chemistry, University of Florence, Via della Lastruccia 3, I-50019 Sesto Fiorentino (Florence), Italy \\ E-mail: silvia.becagli@unifi.it \\ ${ }^{2}$ ENEA, Centro Ricerche Casaccia, PO Box 2400, I-00100 Rome, Italy \\ ${ }^{3}$ Laboratoire de Glaciologie et Géophysique de I'Environnement (CNRS-UJF), 54 rue Molière, BP 96, \\ 38402 Saint-Martin-d'Hères Cedex, France
}

\begin{abstract}
Sea-salt markers $\left(\mathrm{Na}^{+}, \mathrm{Mg}^{2+}\right.$ and $\left.\mathrm{Cl}^{-}\right)$were analyzed in recent snow collected at more than 600 sites located in coastal and central areas of East Antarctica (northern Victoria Land-Dome C-Wilkes Land), in order to understand the effect of site remoteness, transport efficiency and depositional and post-depositional processes on the spatial distribution of the primary marine aerosol. Firn-core, snow-pit and $1 \mathrm{~m}$ integrated superficial snow samples were collected in the framework of the International TransAntarctic Scientific Expeditions (ITASE) project during recent Italian Antarctic Campaigns (1992-2002). The sampling sites were mainly distributed along coast-inland traverses (northern Victoria LandDome $\mathrm{C}$ ) and an east-west transect following the $\mathbf{2 1 0 0} \mathrm{m}$ contour line (Wilkes Land). At each site, the snow ionic composition was determined. Here, we discuss the distribution of sea-spray components $\left(\mathrm{Na}^{+}, \mathrm{Mg}^{2+}\right.$ and $\left.\mathrm{Cl}^{-}\right)$as a function of distance from the sea, altitude and accumulation rate, in order to discover the pulling-down rate, possible fractionating phenomena and alternative sources moving inland from coastal areas. Sea-spray depositional fluxes decrease as a function of distance from the sea and altitude. A two-order-of-magnitude decrease occurs in the first $200 \mathbf{~ k m}$ from the sea, corresponding to about 2000 m a.s.l. Correlations of $\mathrm{Mg}^{2+}$ and $\mathrm{Cl}^{-}$with $\mathrm{Na}^{+}$and trends of $\mathrm{Mg}^{2+} / \mathrm{Na}^{+}$and $\mathrm{Cl}^{-} / \mathrm{Na}^{+}$ratios showed that chloride has other sources than sea spray $(\mathrm{HCl})$ and is affected by post-depositional processes. Accumulation rate higher than $80 \mathrm{~kg} \mathrm{~m}^{-2} \mathrm{a}^{-1}$ preserves the chloride record in the snow. Seaspray atmospheric scavenging is dominated by wet deposition in coastal and inland sites.
\end{abstract}

\section{INTRODUCTION}

Sea spray is the main contributor to the ionic budget of the atmospheric aerosol in Antarctic coastal regions (Delmas, 1992; Wagenbach and others, 1998). Although sea spray is mainly distributed in the super-micrometric aerosol fractions, several studies report that significant sea-salt loads are also present in the sub-micrometric range, especially in particles larger than $0.13 \mu \mathrm{m}\left(\mathrm{O}^{\prime}\right.$ Dowd and others 1993, 1997; Murphy and others, 1998). The sub-micrometric seasalt particles have long atmospheric residence times, allowing their large-scale distribution by long-range transport. This size fraction is also involved in relevant radiative processes: sea spray in the sub-micrometric mode is responsible for the majority of aerosol-scattered sunlight and constitutes a significant fraction of the cloud condensation nuclei (Murphy and other, 1998).

On a global scale, sea spray is mainly produced by bubble bursting and wind blowing on the wave crests (Brimblecombe, 1996). However, the processes leading to sea-salt production from the marine surface in polar regions are somewhat more complex. The emission flux is directly correlated to the wind speed but also depends on seasonal changes in sea-ice coverage. Sea ice affects the primary sea-spray production (its extent increases by $15 \times 10^{6} \mathrm{~km}^{2}$ over winter each year (Gloersen and Campbell, 1991)) in two opposite ways: on the one hand, the sea-ice cover reduces the open-sea surface, weakening the source intensity; on the other hand, its surface is the preferential site for the formation of fragile structures of sea-salt crystals, known as 'frost flowers', caused by evaporation/ condensation sea-water processes during sea-ice growth (Rankin and others, 2000, 2002). Rankin and others (2000, 2002) suggested that frost flowers play a role as sea-salt source to the atmosphere. Sea-spray inputs from the wind ablation of frost flowers are more vigorous during sea-ice formation, and their contribution to the sea-salt aerosol load has been demonstrated for coastal areas (Rankin and others, 2000, 2002). Frost flowers are also thought to have a significant role in sea-salt supply at inland Antarctic sites, and their higher production in glacial periods is postulated to be related to the increase in sea-salt fluxes in the Last Glacial Maximum (Rankin 2000, 2002; Wolff and others, 2003), but experimental evidence is necessary to support these hypotheses. Usually, abrupt sea-salt signatures in ice cores have been attributed to increased open sea water and more efficient transport inland, probably due to stormier weather. Kreutz and others (2000) proposed a method to reconstruct the past sea-level pressure changes in the Amundsen Sea region from Siple Dome (West Antarctica) ice-core stratigraphy. The method was based on the spatial correlation analysis between the monthly sealevel pressure fields and the annual-averaged record of a parameter (empirical orthogonal function) linked to seaspray components.

Due to their role in the atmospheric chemistry and their use as environmental and climatic markers, sea-spray components analyzed in ice cores allow the reconstruction 
of paleo-atmospheric composition, assuming univocal source and preservation in snow layers.

Measurements of ionic chemical components of Antarctic aerosol, snow and ice show that the ratios among the airborne sea-salt compounds can be significantly modified with respect to the bulk sea-water composition (Aristarain and others, 1982, 2002; Legrand and Delmas, 1988; Gjessing, 1989; Mulvaney and others, 1993; Wagenbach and others, 1998). Such fractionating processes can occur, in the atmosphere or in the superficial snow layers, by interaction between sea-spray particles and acidic species $\left(\mathrm{HNO}_{3}\right.$ and $\left.\mathrm{H}_{2} \mathrm{SO}_{4}\right)$, mainly distributed in gas phase or into sub-micrometric aerosol particles. The acid-base exchange reaction leads to the formation of gaseous $\mathrm{HCl}$, which follows different transport pathways than sea-spray particles (Wouters and others 1990; Mclnnes and others, 1994; Mouri and others, 1996; Kerminen and other 2000). Other possible fractionating effects, mainly involving sulfate, can result from selective precipitation of mirabilite $\left(\mathrm{Na}_{2} \mathrm{SO}_{4} 10 \mathrm{H}_{2} \mathrm{O}\right)$ on the pack surface in particular temperature and humidity conditions (Wagenbach and others, 1998) and the above-discussed formation of frost flowers (Rankin and others, 2002). Consequently, achieving extensive and reliable datasets on the sea-spray spatial distribution in coastal and central areas of Antarctica is necessary to clarify the processes controlling sources, transport and deposition of the marine primary aerosol.

In this paper, we discuss the distribution of some seaspray components $\left(\mathrm{Na}^{+}, \mathrm{Mg}^{2+}\right.$ and $\left.\mathrm{Cl}^{-}\right)$at more than 600 sites located in a large, roughly triangular area with the vertices set at northern Victoria Land (NVL), Dome C (DC), central East Antarctica, and Dumont d'Urville (DdU), Wilkes Land. The main goals of this study were: to evaluate the contribution of sea-salt flux to the chemical composition of the snow deposition, as a function of geographical (altitude and distance from the sea) and climatic (accumulation rate) parameters; to identify enrichment or depletion processes, with respect to the sea-water composition, due to the extra contribution of other sources or caused by fractionating effects occurring during the transport or after the deposition; and to clarify the role of accumulation rate in preserving the $\mathrm{Cl}^{-}$record in the snow layers.

\section{SAMPLING AND ANALYSIS}

Superficial snow and/or firn was collected from snow pits and shallow firn cores at more than 600 sites in the NVLDC-DdU sector. The samplings were carried out during the field seasons from 1992/93 to 2001/02, in the framework of the International Trans-Antarctic Scientific Expeditions (ITASE), Station Concordia (French-Italian collaboration) and Programma Nazionale di Ricerche in Antartide (PNRA) programs.

Altogether, four shallow firn cores $(5-50 \mathrm{~m})$ were drilled, 27 snow pits $(1.5-7 \mathrm{~m})$ were hand-dug and 590 snow samples ( $1 \mathrm{~m}$ integrated cores) were collected along coastinland (Terra Nova Bay-DC and GV7-Talos Dome) and east-west (D66-Talos Dome) transects and at several sites located in NVL, within about $300 \mathrm{~km}$ of the Italian base 'Mario Zucchelli'. The sampling area is reported in Figure 1, where the main sampling sites (snow pits and firn core) are shown. Table 1 reports the geographical features of snow
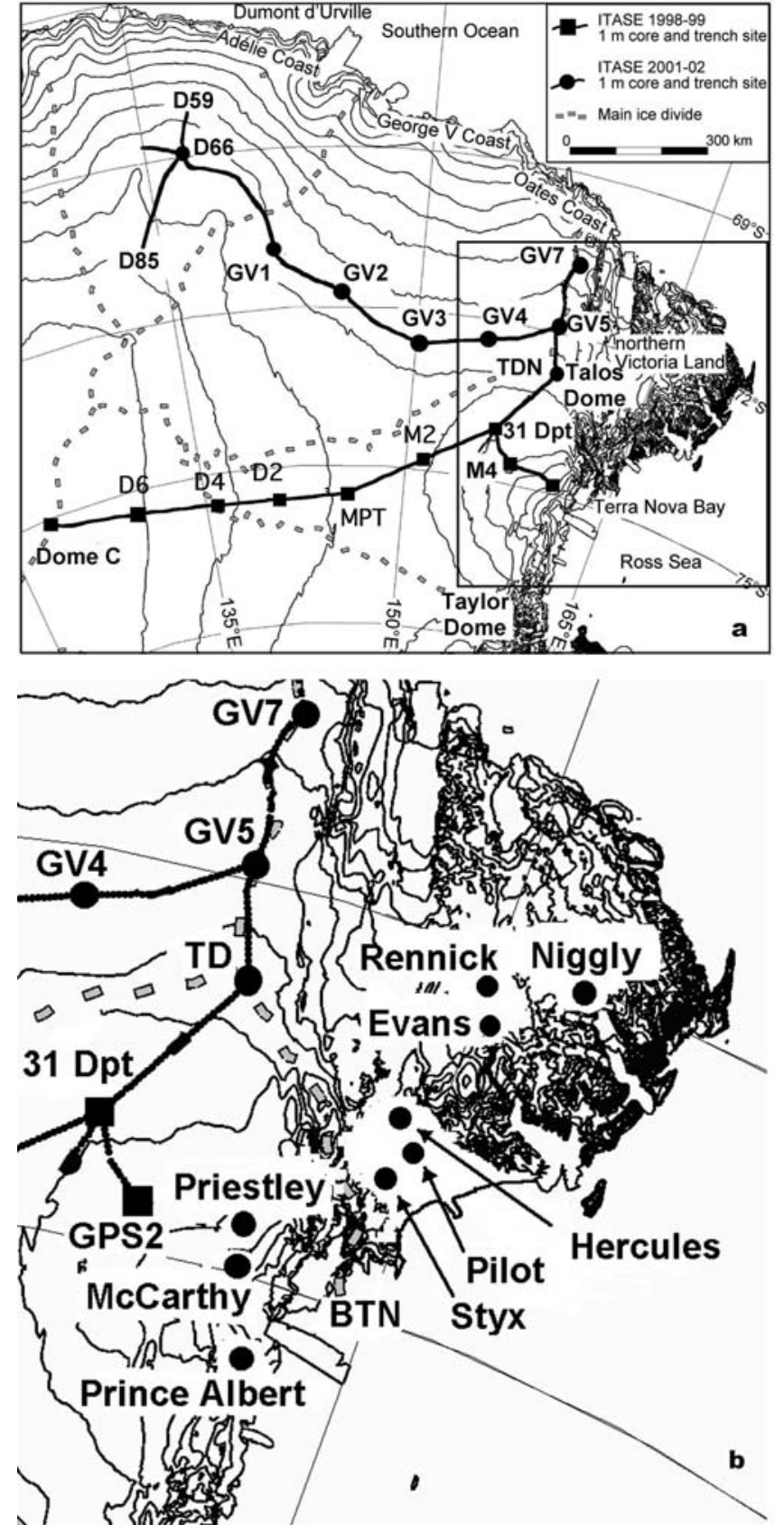

Fig. 1. (a) Map of the sampled area. Squares are related to 1998/99 ITASE traverse; dots indicate snow-pit sites sampled during the 2001/02 ITASE traverse and in NVL region. Contour line interval is $250 \mathrm{~m}$. (b) An enlarged scale of NVL.

pits and shallow firn-core sampling sites. Details of sampling, depth resolution, storage and decontamination procedures have been reported previously (Udisti and others 1998, 1999; Frezzotti and Flora, 2002; Proposito and others, 2002; Becagli and others, 2003, 2004, 2005). Samples were analyzed by ion chromatography for anion and cation content (Gragnani and others, 1998; Udisti and others, 2004a). Here, we discuss the spatial distribution of the depositional-flux mean values of sea-spray components $\left(\mathrm{Na}^{+}, \mathrm{Mg}^{2+}\right.$ and $\left.\mathrm{Cl}^{-}\right)$at each site. The mean chemical composition was calculated on the most superficial firn-core and snow-pit samples, covering approximately the last 5 years of snow deposition. At Dome C, mean data were calculated on three snow pits, in order to obtain a larger 
Table 1. Geographical features of snow pits and firn-core sampling sites, sampling methods and year of sampling

\begin{tabular}{|c|c|c|c|c|c|c|}
\hline \multirow[t]{2}{*}{ Site } & \multirow[t]{2}{*}{ Lat. (S) } & \multirow[t]{2}{*}{ Long. (E) } & \multirow{2}{*}{$\begin{array}{c}\text { Elevation } \\
\text { ma.s.I. }\end{array}$} & \multirow{2}{*}{$\begin{array}{c}\text { Distance } \\
\text { from sea } \\
\text { km }\end{array}$} & \multirow[t]{2}{*}{ Sampling method } & \multirow[t]{2}{*}{$\begin{array}{c}\text { Sampling year } \\
\text { (Antarctic campaign) }\end{array}$} \\
\hline & & & & & & \\
\hline GPS2 & $74^{\circ} 38.69^{\prime}$ & $157^{\circ} 30.13^{\prime}$ & 1776 & 167 & Snow pit & 1998/99 \\
\hline 31Dpt & $74^{\circ} 01.52^{\prime}$ & $155^{\circ} 57.6^{\prime}$ & 2065 & 238 & Snow pit & 1998/99 \\
\hline $\mathrm{M} 2$ & $74^{\circ} 48.27^{\prime}$ & $151^{\circ} 16.17^{\prime}$ & 2308 & 327 & Snow pit & 1998/99 \\
\hline Mid Point (MPT) & $75^{\circ} 32.16^{\prime}$ & $145^{\circ} 51.43^{\prime}$ & 2454 & 460 & Snow pit & 1998/99 \\
\hline D2 & $75^{\circ} 37.33^{\prime}$ & $140^{\circ} 37.84^{\prime}$ & 2611 & 587 & Snow pit & 1998/99 \\
\hline D4 & $75^{\circ} 35.88^{\prime}$ & $135^{\circ} 49.89^{\prime}$ & 2792 & 692 & Snow pit & 1998/99 \\
\hline D6 & $75^{\circ} 26.85^{\prime}$ & $129^{\circ} 48.53^{\prime}$ & 3024 & 851 & Snow pit & 1998/99, 1997/98 \\
\hline Dome C & $75^{\circ} 06^{\prime}$ & $123^{\circ} 21^{\prime}$ & 3233 & 1000 & Snow pit & 1998/99, 2000/01 \\
\hline D66 & $68^{\circ} 56.38^{\prime}$ & $136^{\circ} 56.112^{\prime}$ & 2333 & 280 & Snow pit & $2001 / 02$ \\
\hline GV1 & $70^{\circ} 52.266^{\prime}$ & $141^{\circ} 23.00^{\prime}$ & 2244 & 400 & Snow pit & $2001 / 02$ \\
\hline GV2 & $71^{\circ} 42.702^{\prime}$ & $145^{\circ} 15.786^{\prime}$ & 2143 & 395 & Snow pit & $2001 / 02$ \\
\hline GV4 & $72^{\circ} 23.317^{\prime}$ & $154^{\circ} 29.05^{\prime}$ & 2126 & 330 & Snow pit & 2001/02 \\
\hline GV5 & $71^{\circ} 53.22^{\prime}$ & $158^{\circ} 32.216^{\prime}$ & 2184 & 200 & Snow pit & $2001 / 02$ \\
\hline GV7 & $70^{\circ} 41.052^{\prime}$ & $158^{\circ} 51.749^{\prime}$ & 1947 & 95 & Snow pit & 2001/02 \\
\hline Talos Dome & $72^{\circ} 46.235^{\prime}$ & $159^{\circ} 04.545^{\prime}$ & 2316 & 250 & Snow pit and firn core & 2001/02, 1996/97 \\
\hline Priestley Névé & $73^{\circ} 38.3^{\prime}$ & $160^{\circ} 38.5^{\prime}$ & 1983 & 120 & Snow pit & $1993 / 94$ \\
\hline Rennick Glacier & $73^{\circ} 14.840^{\prime}$ & $162^{\circ} 29.060^{\prime}$ & 2310 & 220 & Snow pit & 1993/94 \\
\hline McCarthy Ridge & $74^{\circ} 36.00^{\prime}$ & $163^{\circ} 03.131^{\prime}$ & 850 & 40 & Snow pit and firn core & $1993 / 94,1992 / 93$ \\
\hline Styx Glacier & $73^{\circ} 51.940^{\prime}$ & $163^{\circ} 41.715^{\prime}$ & 1660 & 50 & Snow pit and firn core & 1993/94, 1991/92 \\
\hline Hercules Névé & $73^{\circ} 06.378^{\prime}$ & $165^{\circ} 27.785^{\prime}$ & 2960 & 90 & Snow pit and firn core & $1993 / 94,1992 / 93$ \\
\hline Pilot Glacier & $73^{\circ} 15.835^{\prime}$ & $163^{\circ} 30.772^{\prime}$ & 2100 & 60 & Snow pit & 1993/94 \\
\hline Prince Albert & $75^{\circ} 10.30^{\prime}$ & $162^{\circ} 07.53^{\prime}$ & 800 & 40 & Snow pit & 1993/94 \\
\hline Niggly Névé & $72^{\circ} 41.15^{\prime}$ & $166^{\circ} 58.1^{\prime}$ & 2610 & 120 & Snow pit & 1993/94 \\
\hline Evans Névé & $74^{\circ} 42.2^{\prime}$ & $166^{\circ} 56.4^{\prime}$ & 2520 & 140 & Snow pit & 1996/97 \\
\hline
\end{tabular}

significance at a site involved in deep ice-core drilling (EPICA community, 2004). Dome $\mathrm{C}$ mean values are related to snow layers younger than 1991 (about the first $0.5 \mathrm{~m}$ ), as revealed by the sulfate peak of the Pinatubo (Philippines) eruption, recorded in the Antarctic ice sheet in 1991. The $1 \mathrm{~m}$ integrated samples cover periods of about 5-20 years as a function of the site accumulation rate. The dating procedures were based on stratigraphies of seasonal markers (Udisti, 1996; Stenni and others, 2000), evaluated by the AD 1965-66 $\beta$-tritium peak or estimated from the accumulation rate/temperature and accumulation rate/latitude relationships (Frezzotti and others, 2004; Magand and others, 2004).

\section{RESULTS AND DISCUSSION}

\subsection{Calculation of sea-salt and non-sea-salt fractions}

$\mathrm{Na}^{+}, \mathrm{Mg}^{2+}$ and $\mathrm{Cl}^{-}$have possible alternative sources with respect to sea spray. $\mathrm{Na}^{+}$and $\mathrm{Mg}^{2+}$ also originate from crustal primary aerosol, and $\mathrm{Cl}^{-}$is also supplied by adsorption processes of gaseous $\mathrm{HCl}$, in turn mainly originating from acid-base chemical exchange between $\mathrm{NaCl}$ and $\mathrm{HNO}_{3}$ or $\mathrm{H}_{2} \mathrm{SO}_{4}$, into aerosol particles or directly on the snow surface (Aristarain and others, 1982; Legrand and Delmas, 1988; Gjessing, 1989; Mulvaney and others, 1993; Wagenbach and others, 1998; Aristarain and Delmas, 2002).

The $\mathrm{Na}^{+}$sea-salt fraction $\left(\mathrm{ssNa}^{+}\right)$was evaluated by subtracting from the measured total $\mathrm{Na}^{+}$concentration the crustal contribution, calculated on the basis of the $\mathrm{Ca}^{2+}$ content. Since $\mathrm{Ca}^{2+}$ also has marine and crustal sources, its non-sea-salt fraction $\left(\mathrm{nssCa}^{2+}\right)$ must also be evaluated. We used a simple two-equation system to evaluate sea-spray and crustal contribution of $\mathrm{Na}^{+}$and $\mathrm{Ca}^{2+}$ :

$$
\begin{aligned}
\mathrm{ssNa}^{+} & =\mathrm{Na}^{+}-\mathrm{nssNa}^{+} \\
& =\mathrm{Na}^{+}-\mathrm{nssCa}^{2+}\left(\mathrm{Na}^{+} / \mathrm{Ca}^{2+}\right)_{\text {crust }} \\
\mathrm{nssCa}^{2+} & =\mathrm{Ca}^{2+}-\mathrm{ssCa}^{2+} \\
& =\mathrm{Ca}^{2+}-\mathrm{ssNa}^{+}\left(\mathrm{Ca}^{2+} / \mathrm{Na}^{+}\right)_{\text {seawater }} \\
\left(\mathrm{Na}^{+} / \mathrm{Ca}^{2+}\right)_{\text {crust }} & =0.56(\mathrm{w} / \mathrm{w}) \quad(\text { Bowen, } 1979) \\
\left(\mathrm{Ca}^{2+} / \mathrm{Na}^{+}\right)_{\text {seawater }} & =0.038(\mathrm{w} / \mathrm{w}) \quad(\text { Bowen, 1979) }
\end{aligned}
$$

where $\left(\mathrm{Na}^{+} / \mathrm{Ca}^{2+}\right)_{\text {crust }}$ is the mean ratio in the Earth's crust and $\left(\mathrm{Ca}^{2+} / \mathrm{Na}^{+}\right)_{\text {seawater }}$ the mean ratio in bulk sea water. Ratios are expressed as weight on weight (w/w).

Though $\mathrm{ssSO}_{4}{ }^{2-}$ was also considered as a sea-spray component, we do not discuss it for two main reasons: (1) $\mathrm{SsSO}_{4}{ }^{2-}$ is a minor fraction of the sulfate budget at the great majority of the sampled sites (the major contribution comes from oceanic biogenic source of $\mathrm{H}_{2} \mathrm{SO}_{4}$; Becagli and others, 2005); and (2) a large uncertainty affects the $\mathrm{ssSO}_{4}{ }^{2-}$ calculation because the bulk sea-water ratio usually used $\left(\mathrm{SO}_{4}{ }^{2-} / \mathrm{Na}^{+}=0.253 \mathrm{w} / \mathrm{w}\right)$ was changed in winter sea-spray aerosol by precipitation of mirabilite $\left(\mathrm{Na}_{2} \mathrm{SO}_{4}\right)$, temperaturetuned (Wagenbach and others, 1998). In addition, Rankin and others (2002) supposed that the ice flowers formed on the sea-ice surface during its seasonal growth by volatilizationcondensation processes, similarly weakened in $\mathrm{SO}_{4}{ }^{2-}$ with respect to sea-water bulk composition, could constitute a major source of sea-spray aerosol, at least for coastal sites and in the winter period. The contribution of mirabilite precipitation and ice-flower growth to the global budget of annual $\mathrm{SsSO}_{4}{ }^{2-}$ deposition in areas located at different distances 


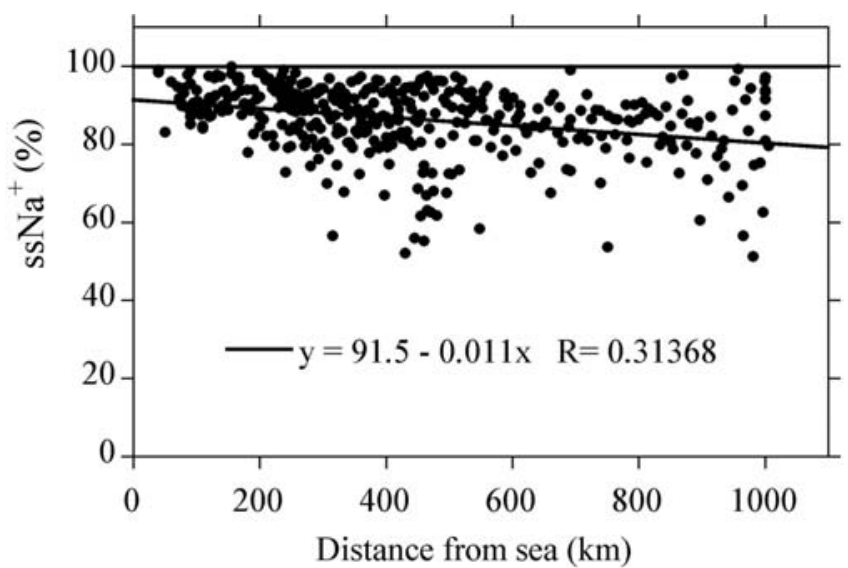

Fig. 2. Percentage contribution of $\mathrm{ssNa}^{+}$with respect to total $\mathrm{Na}^{+}$ reported as a function of distance from the sea.

from the sea and altitudes is difficult to quantify, making the uncertainties related to $\mathrm{SsSO}_{4}{ }^{2-}$ calculation too large.

Possible enrichments or depletions of $\mathrm{Mg}^{2+}$ and $\mathrm{Cl}^{-}$, with respect to the bulk sea-water composition, are discussed in section 3.3, based on their linear regression with $\mathrm{ssNa}^{+}$and on the trends of the $\mathrm{Mg}^{2+} / \mathrm{ssNa}^{+}$and $\mathrm{Cl}^{-} / \mathrm{ssNa}^{+}$ratios.

\subsection{Geographical variability}

Figure 2 shows the ss $\mathrm{Na}^{+}$percentage fraction as a function of distance from the sea for all the sampling sites. The seasalt contribution to the total $\mathrm{Na}^{+}$budget is always dominant ( $>80 \%$ for most sites). It is lower only at a few stations in NVL characterized by crustal contribution from ice-free areas of the Transantarctic Chain and at some sites in Wilkes Land affected by a particular atmospheric circulation pattern (Magand and others, 2004). Indeed, as a consequence of increasing remoteness, the percentage of $\mathrm{ssNa}^{+}$shows a slight and noisy decreasing trend as distance from the sea increases.

In order to obtain a higher significance between the seaspray snow content and the site location (altitude and distance from the sea), total depositional flux was here preferred to concentration, as a parameter less affected by the large changes in accumulation rate observed in the studied area. It is important to clarify that flux represents the total net deposition of an atmospheric component by both wet and dry removal processes. The flux is closely related to the atmospheric aerosol load only for components measured at sites where dry deposition is dominant (Mayewsky and Legrand, 1990; Udisti and others, 2004b). Even so, the relative contribution of wet and dry deposition to the snow content of atmospheric components is valuable by a graphic elaboration, if a number of sites are sampled in the same area (Legrand and Delmas, 1987; Fischer and Wagenbach, 1996). This approach applied to coastal and inner areas is described in section 3.5.

Total (wet and dry) depositional fluxes of $\mathrm{Na}^{+}, \mathrm{Mg}^{2+}$ and $\mathrm{Cl}^{-}$are calculated by multiplying concentration $\left(\mu \mathrm{g} \mathrm{L}^{-1}\right)$ by the mean annual accumulation rate $\left(\mathrm{kg} \mathrm{m}^{-2} \mathrm{a}^{-1}\right)$ at the sampling site:

$$
\begin{aligned}
F_{\text {tot }}=C A\left(\mu \mathrm{g} \mathrm{m}^{-2} \mathrm{a}^{-1}\right), \\
\text { considering snow melted density }=1 .
\end{aligned}
$$

Snow composition along the coast-inland transect reflects aerosol fractionating effects occurring during the transport of
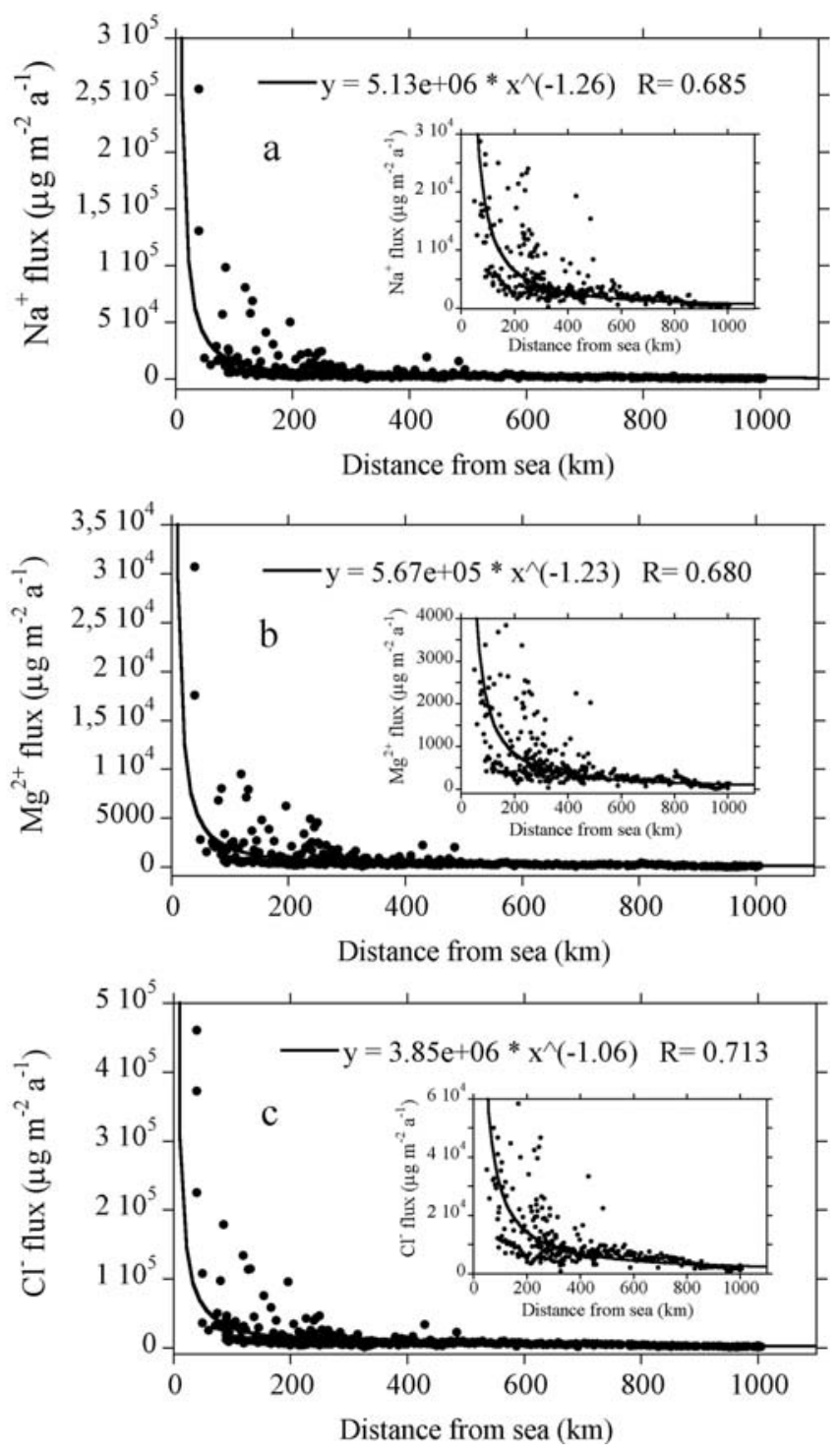

Fig. 3. $\mathrm{Na}^{+}(\mathrm{a}), \mathrm{Mg}^{2+}$ (b) and $\mathrm{Cl}^{-}$(c) depositional fluxes as a function of distance from the sea. Smaller plots inside the panels show the same plot at lower $y$ scale.

humid air masses from the oceanic source areas to the deposition site. In this way, the parameters mainly affecting the reconstruction of the load and chemical composition of the atmospheric aerosol are accumulation rate, altitude and temperature. In the NVL-DC-DdU area, these factors are interrelated: a positive relationship links distance from the sea and altitude, while these two parameters are inversely correlated to the temperature (Frezzotti and others, 2004; Magand and others, 2004). We have chosen distance from the sea as the reference parameter in evaluating the seaspray spatial trend in this Antarctic region.

The inverse correlation between sea-spray atmospheric load as revealed by the snow composition, and distance from the sea is clear in Figure 3. The sharpest decrease in depositional fluxes of $\mathrm{Na}^{+}, \mathrm{Mg}^{2+}$ and $\mathrm{Cl}^{-}$occurs in the first $200 \mathrm{~km}$ from the sea (see also smaller plots at lower $y$ scale). From $500 \mathrm{~km}$ inland, the fluxes of the three components reach stable values about two orders of magnitude lower than those measured at the coastal sites. When plotted as a function of altitude (not shown), depositional fluxes show the most rapid decrease in the first 2000 ma.s.l. This pattern 

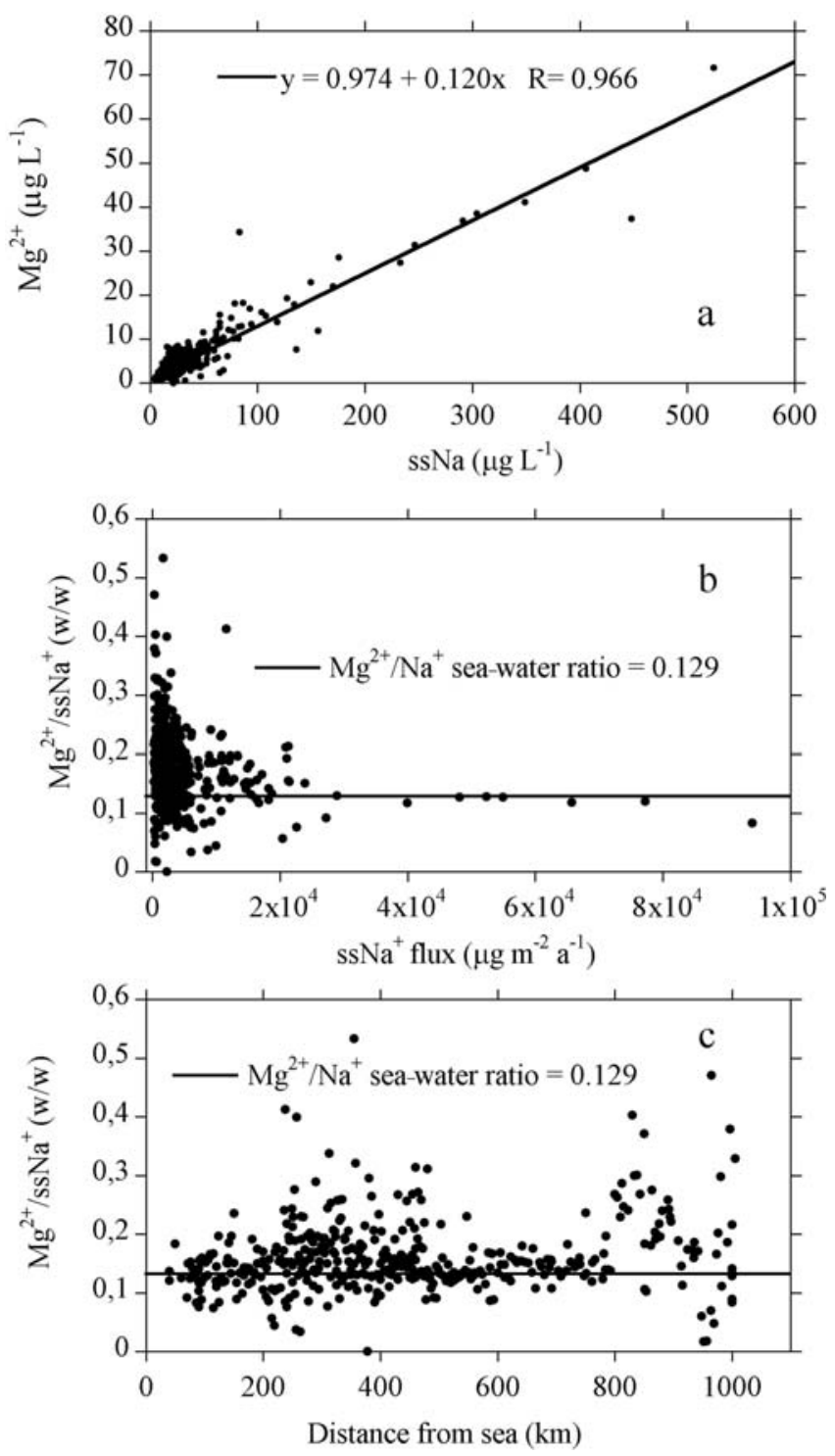

Fig. 4. (a) Correlation plot between $\mathrm{Mg}^{2+}$ and $\mathrm{ssNa}^{+}$. (b, c) $\mathrm{Mg}^{2+} /$ $\mathrm{Na}^{+}$ratio reported as a function of $\mathrm{ssNa}^{+}$depositional flux (b) and distance from the sea (c). Lines in (b) and (c) represent the $\mathrm{Mg}^{2+}$ / $\mathrm{Na}^{+}$ratio in sea water.

is caused by the fast decrease in atmospheric load of aerosol particles mainly belonging to the super-micrometric classes, which undergo more efficient atmospheric scavenging processes by wet and dry deposition (short atmospheric residence time) (e.g. Minikin and others 1994; Udisti and others, 1998; Becagli and others, 2003; Traversi and others, 2004). Aerosol measurements at Terra Nova Bay (Kerminen and others, 2000; Migliori and others, 2002; Fattori and others, 2004, 2005) and at Dome C (Udisti and others, 2004a) show the sea-spray components are mainly distributed in the 'coarse' aerosol fraction, with a prevalent mode around 2.1-1.1 $\mu \mathrm{m}$ (Innocenti and others, 2004). The trends of sea-salt components shown in Figure 3 show that the first $200 \mathrm{~km}$ from the sea, corresponding to a $\sim 2000 \mathrm{~m}$ a.s.l. altitude step, could be considered a critical threshold for sea-spray penetration in the central Antarctic area.

The decreasing pattern can be described by a power function. Figure 3 shows the curve-fits (correlation coefficient $R=0.68-0.71, n=621)$. The constant flux values from $500 \mathrm{~km}$ inland for $\mathrm{Na}^{+}$and $\mathrm{Mg}^{2+}$ could support the
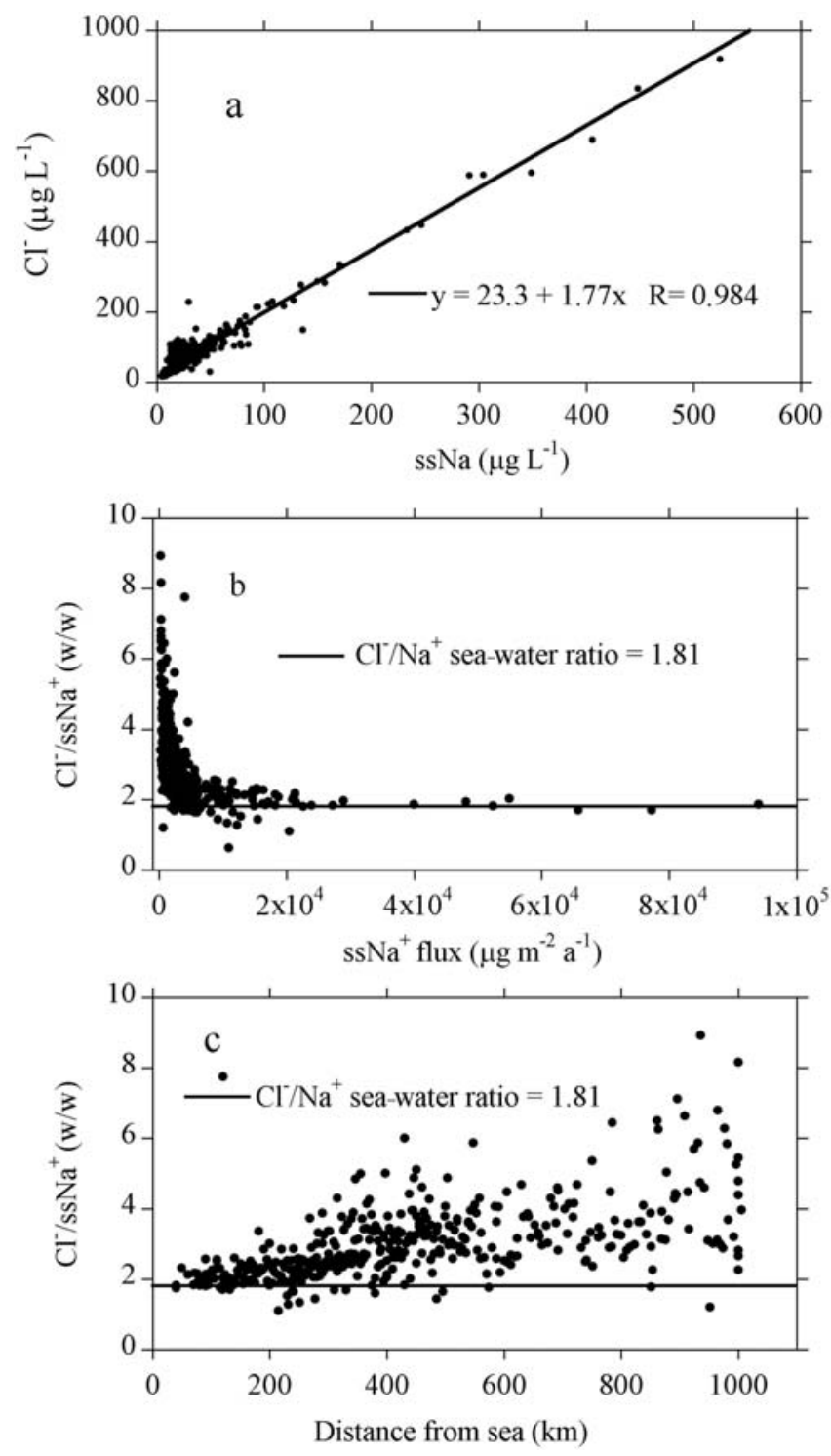

Fig. 5. Same as Figure 4, but for $\mathrm{Cl}^{-}$instead of $\mathrm{Mg}^{2+}$.

hypothesis that background sea-spray aerosol reaches the central areas of Antarctica due to the long residence time in the atmosphere of sea-spray particles in the accumulation mode $(\sim 0.3-1 \mu \mathrm{m})$ (Shaw, 1989; Murphy and others, 1998).

The different pattern of chloride flux (Fig. 3c), which shows a continuous decreasing trend inland (although slightly less so with respect to the first $200 \mathrm{~km}$ step), can be explained by the increasing effects of post-depositional re-emission of $\mathrm{HCl}$ into the atmosphere as accumulation rate decreases, i.e. the distance from the sea increases (see section 3.4).

\subsection{Correlations between $\mathrm{Mg}^{2+}$ or $\mathrm{Cl}^{-}$and $\mathrm{ss} \mathrm{Na}^{+}$}

To identify possible other sources of $\mathrm{Mg}^{2+}$ and $\mathrm{Cl}^{-}$or fractionating effects of sea spray during the atmospheric transport, we plotted the $\mathrm{Mg}^{2+}$ and $\mathrm{Cl}^{-}$concentrations vs the ss $\mathrm{Na}^{+}$concentration and the $\mathrm{Mg}^{2+} / \mathrm{ssNa}^{+}$and $\mathrm{Cl}^{-} / \mathrm{ssNa}^{+}$ ratios as functions of $\mathrm{ssNa}^{+}$flux and distance from the sea.

Figures $4 \mathrm{a}$ and $5 \mathrm{a}$ show good correlations between $\mathrm{Mg}^{2+}$ or $\mathrm{Cl}^{-}$and $\mathrm{ssNa}^{+}$at all sites $(R=0.966$ and 0.984 , respectively). The correlation is also seen at sites where sea-spray input is low. The linear regression slopes $(0.120$ for 
$\mathrm{Mg}^{2+}, 1.77$ for $\mathrm{Cl}^{-}$) are very close to the bulk sea-water ratio (0.129 and $1.81 \mathrm{w} / \mathrm{w}$, respectively), confirming that sea spray mainly drives the relationships.

While the $\mathrm{Mg}^{2+}$ vs $\mathrm{ssNa}^{+}$regression line shows an insignificant $y$ intercept (about $1 \mathrm{ppb}$ ), the $\mathrm{Cl}^{-}$vs ss $\mathrm{Na}^{+}$ intercept value (about $23 \mathrm{ppb}$ ) shows that $\mathrm{Cl}^{-}$in snow precipitation is supplied by other sources than sea spray, which becomes more and more evident as the sea-spray load decreases (low ss $\mathrm{Na}^{+}$flux, i.e. when the distance from the sea increases; Fig $5 \mathrm{~b}$ ). Figure $4 \mathrm{~b}$ and c show the pattern of the $\mathrm{Mg}^{2+} / \mathrm{ss} \mathrm{Na}^{+}$ratio as a function of the $\mathrm{ss} \mathrm{Na}^{+}$flux and distance from the sea. When $\mathrm{ssNa}^{+}$decreases, i.e. at low sea-spray input, a large increase in data scattering is visible, but no particular trend is shown. This scattering is mainly attributed to the natural variability of the atmospheric transport of sea spray because the analytical reproducibility at ppb levels is better than 3\% for both components (total reproducibility better than $10 \%$ ). By plotting the $\mathrm{Mg}^{2+} / \mathrm{ss} \mathrm{Na}^{+}$ ratio vs distance from the sea (Fig. 4c), the values stay near the bulk sea-water ratio (shown by the line at $0.129 \mathrm{w} / \mathrm{w}$ ) without sharp shifts. We conclude that sea spray is the main source of $\mathrm{Mg}^{2+}$ at all stations and no significant fractionating effects occur during the transport or deposition processes. By contrast, $\mathrm{Cl}^{-}$exhibits a clear, large enrichment, with respect to the bulk sea-water composition, as the sea-spray load decreases (Fig. 5b). The $\mathrm{Cl}^{-} / \mathrm{ssNa}^{+}$ratio reaches values up to five times higher than sea-water composition when the ss $\mathrm{Na}^{+}$flux is lower than $2 \times 10^{4} \mu \mathrm{g} \mathrm{m}^{-2} \mathrm{a}^{-1}$. Figure $5 \mathrm{c}$ shows this enrichment is not abrupt, but progressively increases with distance from the sea. Therefore, other sources than sea spray for $\mathrm{Cl}^{-}$deposition at inland Antarctic sites must be considered. As discussed in section 3.1, the major non-seasalt source for $\mathrm{Cl}^{-}$is the deposition of $\mathrm{HCl}$, mainly formed by acid-base exchange between $\mathrm{NaCl}$ and atmospheric acidic species $\left(\mathrm{H}_{2} \mathrm{SO}_{4}, \mathrm{HNO}_{3}\right)$. The contribution of this additional input becomes more evident when the main source (sea spray) is low.

\subsection{Post-depositional re-emission of $\mathbf{H C l}$}

The increase of the $\mathrm{Cl}^{-} / \mathrm{ss} \mathrm{Na}^{+}$ratio by the extra contribution of $\mathrm{HCl}$ deposition is evident only because we considered mean values calculated on the uppermost snow layers, related to the first $0.5-1.0 \mathrm{~m}$ at sites with low accumulation rate. Actually, post-depositional processes leading to reemission into the atmosphere of $\mathrm{HCl}$ directly deposited on the snow surface, absorbed into cloud droplets or adsorbed on the snowflake and ice-crystal surface heavily affect chloride depth profiles. Snow acidity is the key parameter for preservation of chloride in the snow layers. Glacial snow, enriched in crustal particles, showed much higher chloride concentrations by transformation of volatile $\mathrm{HCl}$ in nonvolatile salts (Röthlisberger and others, 2002; Udisti and others, 2004b). In the present condition, when Antarctic snow is acidic, especially at inland sites where $\mathrm{H}_{2} \mathrm{SO}_{4}$ and $\mathrm{HNO}_{3}$ dominate the ionic budget (Migliori and others, 2002; Udisti and others, 2004a; Fattori and others 2005), chloride is preserved only when the site accumulation rate is relatively high (Traversi and others, 2000). Here, we aim to evaluate the snow accumulation rate threshold able to preserve the original chloride deposition.

Figure 6 shows the depth profiles of the $\mathrm{Cl}^{-} / \mathrm{Na}^{+}$ratio in sites where high-resolution $(2.5-5.0 \mathrm{~cm})$ chemical analysis was carried out on snow-pit and firn-core samples. Accumulation rates range from $213 \mathrm{~kg} \mathrm{~m}^{-2} \mathrm{a}^{-1}$ at D66 to
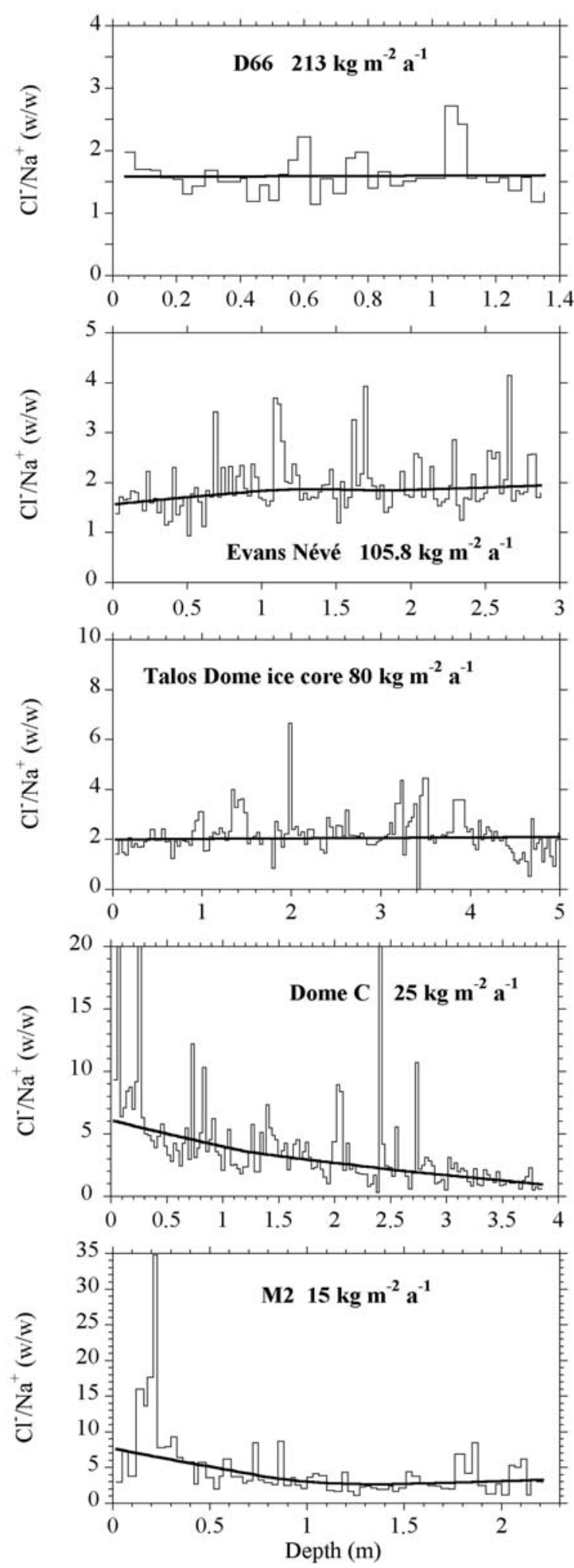

Fig. 6. $\mathrm{Cl}^{-} / \mathrm{Na}^{+}$depth profiles from snow pits and firn core related to selected sites with different accumulation rates.

$15 \mathrm{~kg} \mathrm{~m}^{-2} \mathrm{a}^{-1}$ at M2. At the first three stations (D66, Evans Névé and Talos Dome), the $\mathrm{Cl}^{-} / \mathrm{Na}^{+}$ratio does not show a decreasing trend with depth. Their heavily smoothed trends (line in the plots) show constant values (1.5-2) close to the bulk sea-water composition $(1.81 \mathrm{w} / \mathrm{w})$. By contrast, the stations located far from the sea and/or characterized by low accumulation rates show a sharp decrease in the $\mathrm{Cl}^{-} / \mathrm{Na}^{+}$ ratio from high superficial values (higher than sea water) to 


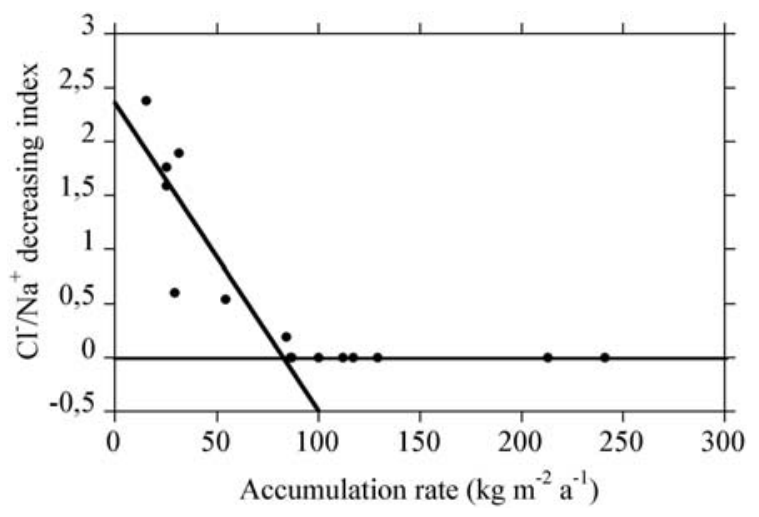

Fig. $7 . \mathrm{Cl}^{-} / \mathrm{Na}^{+}$decreasing index as a function of accumulation rate. See text for calculation of decreasing index.

values equal to or lower than sea-water composition on the snow-pit bottom. In such stations, where sea-spray contribution is low, the $\mathrm{HCl}$ extra source to chloride is clearly seen in the uppermost layers $\left(\mathrm{Cl}^{-} / \mathrm{Na}^{+}\right.$higher than sea water), but accumulation rate is not sufficient to preserve the $\mathrm{HCl}$ original deposition, leading to progressive loss of chloride. In addition, the high snow acidity, as revealed by ionic balances (Udisti and others, 2004a), causes chemical exchange between $\mathrm{NaCl}$ particles and acidic species (mainly $\mathrm{H}_{2} \mathrm{SO}_{4}$ ), leading to further loss of chloride $\left(\mathrm{Cl}^{-} / \mathrm{Na}^{+}\right.$values lower than sea water).

To evaluate the accumulation rate threshold for the chloride preservation, we plotted a $\mathrm{Cl}^{-} / \mathrm{Na}^{+}$decreasing index (D1) as a function of accumulation rate (Fig. 7). The $\mathrm{Cl}^{-} / \mathrm{Na}^{+}$is the decrease in $\mathrm{Cl}^{-} / \mathrm{Na}^{+}$ratio for each depth meter evaluated in the uppermost $2.0 \mathrm{~m}$ snow layer. $\mathrm{Cl}^{-} / \mathrm{Na}^{+}$ratios were measured on the smoothed curves shown in Figure 6, in order to minimize the high background noise. Two simple linear regressions were drawn for high accumulation rates (where no re-emission occurs: $\mathrm{Cl}^{-} / \mathrm{Na}^{+} \mathrm{DI}=0$ ) and for low accumulation rates. The intercept between the regression lines roughly indicates the accumulation rate from which chloride is preserved in the snow in the present acidic conditions. This threshold is about $80 \mathrm{~kg} \mathrm{~m}^{-2} \mathrm{a}^{-1}$ for the NVL-DC-DdU sector.

\subsection{Wet and dry contributions to net depositional fluxes}

The net depositional flux of sea spray is the result of three contributions (Fischer and Wagenbach, 1996):

$$
F_{\text {tot }}=F_{\mathrm{d}}+F_{\mathrm{w}}+\Delta F
$$

where $F_{\mathrm{d}}$ and $F_{\mathrm{w}}$ indicate the dry and wet deposition fluxes and $\Delta F$ accounts for post-depositional processes (such as reemission into the atmosphere of chloride). The term $\Delta F$ can be disregarded for $\mathrm{Na}^{+}$and $\mathrm{Mg}^{2+}$ because they are irreversibly deposited in the snow. It also plays a minor role for chloride if only very superficial layers are considered. Therefore, for the uppermost layers we have:

$$
F_{\text {tot }}=F_{\mathrm{d}}+F_{\mathrm{w}}=F_{\mathrm{d}}+C_{\mathrm{p}} A,
$$

where $C_{\mathrm{p}}$ is the concentration associated with the wet deposition and $A$ is the accumulation rate. By assuming $C_{\mathrm{p}}$ constant for precipitation occurring along coast-inland pathways (e.g. Fischer and Wagenbach, 1996), a linear regression should be obtained when plotting $F_{\text {tot }}$ as a function of accumulation rate; the $y$ intercept (flux axis) of
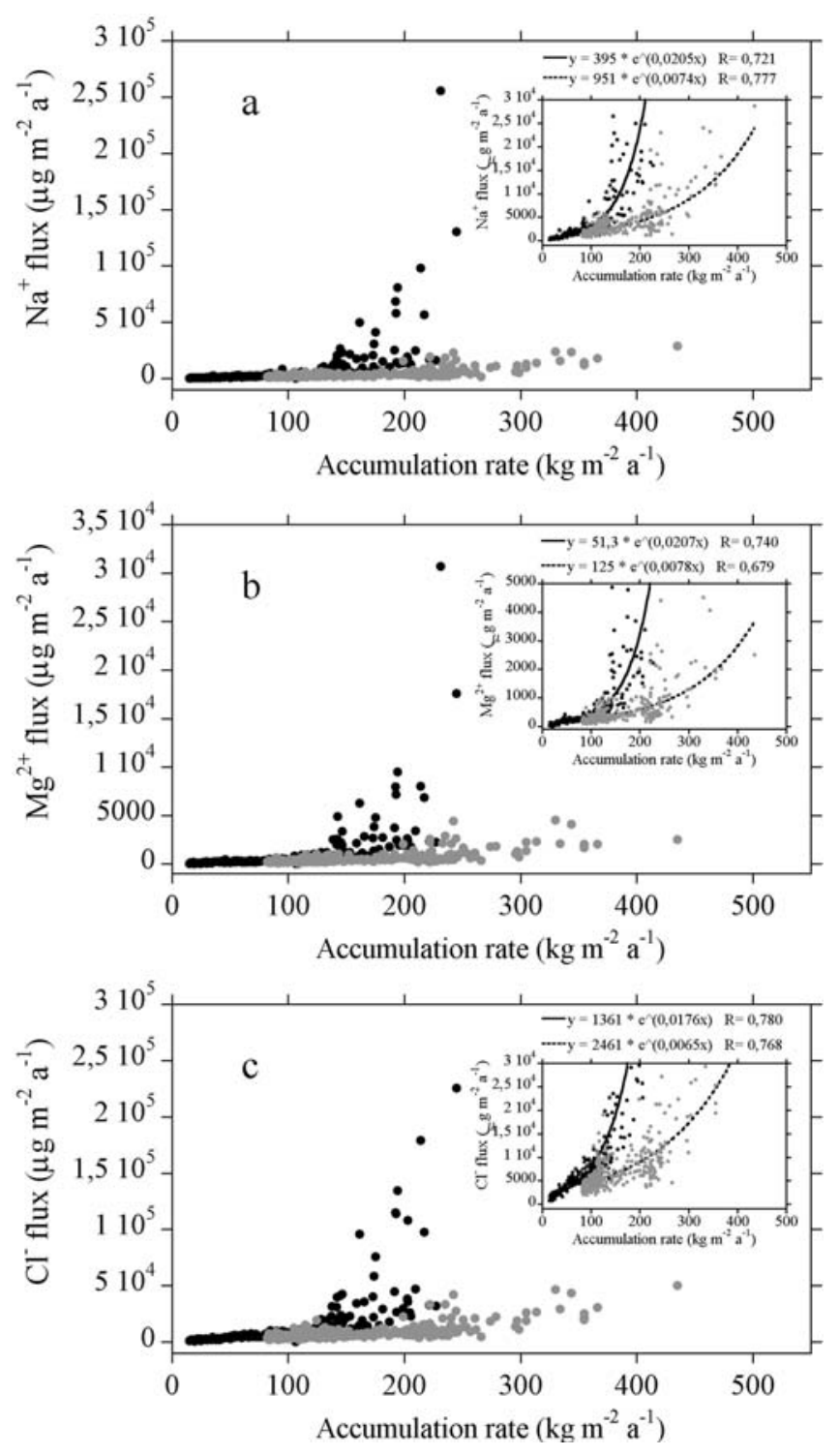

Fig. 8. $\mathrm{Na}^{+}(\mathrm{a}), \mathrm{Mg}^{2+}$ (b) and $\mathrm{Cl}^{-}$(c) depositional fluxes as a function of accumulation rate: grey dots represent Wilkes Land sites and dark dots represent NVL sites. Smaller plots inside show the same plot at lower $y$ scale.

such a regression line represents the contribution of the dry deposition. By plotting $\mathrm{Na}^{+}, \mathrm{Mg}^{2+}$ and $\mathrm{Cl}^{-}$total fluxes as a function of accumulation rate (Fig. 8a-C), an exponential regression seems better able to represent the trends of NVL-DC and sectors (see Fig. $8 \mathrm{a}-\mathrm{C}$ ).

$$
F_{\text {tot }}=F \mathrm{e}^{K A} \text {, }
$$

where $F$ is the values of $F_{\text {tot }}$ when $A=0$ and can be considered as the dry deposition flux and $K$ is a term related to the wet deposition which is different as a function of airmass transport pathway.

The highest fluxes measured at the NVL coastal sites indicate a larger sea-spray input than that occurring in WL at similar accumulation rate. This is due to the different atmospheric circulation pattern in the two sectors: NVL is affected by air masses coming directly from the Ross Sea, whereas Wilkes Land presents more continental conditions and low intrusion of atmospheric moisture correlated with the persistence of higher atmospheric pressure in the central areas of the Wilkes Land transect (Magand and others, 
2004). The exponential regressions drawn in Figure $8 \mathrm{a}-\mathrm{c}$ improve the estimation of the $y$-intercept values, allowing evaluation of the dry contribution (when accumulation rate tends to zero). Unlike that observed for $\mathrm{H}_{2} \mathrm{SO}_{4}$ and MSA (Becagli and others, 2005), dry deposition seems to play a minor role in sea-spray scavenging processes. This means that, in the Ross Sea and Pacific Ocean sectors, wet removal accounts for the majority of sea-spray deposition both in coastal and in inland areas.

\section{CONCLUSIONS}

The spatial distribution of sea-spray components $\left(\mathrm{Na}^{+}, \mathrm{Mg}^{2+}\right.$ and $\mathrm{Cl}^{-}$) in superficial snow was evaluated by site-mean values calculated at 621 stations located in the NVL-DCDdU sector. $\mathrm{ssNa}^{+}$is the dominant fraction of the $\mathrm{Na}^{+}$ budget, contributing more than $80 \%$ at the majority of sites. Sea-spray depositional fluxes are heavily controlled by distance from the sea and altitude. The first $200 \mathrm{~km}$ from the sea and the initial altitude step of $2000 \mathrm{~m}$ a.s.l. constitute threshold values in pulling down the sea spray by wet deposition. Areas beyond these limits show depositional fluxes of $\mathrm{Na}^{+}, \mathrm{Mg}^{2+}$ and $\mathrm{Cl}^{-}$about 100 times lower. Sea spray is also the dominant source for $\mathrm{Mg}^{2+}$ for inland sites, as shown by the $\mathrm{Mg}^{2+}$ vs $\mathrm{ssNa}^{+}$linear regression and by the trends of the $\mathrm{Mg}^{2+} / \mathrm{Na}^{+}$ratio as a function of $\mathrm{ssNa}^{+}$flux or distance from the sea. Chloride shows other sources than sea spray. In spite of a good linear correlation with $\mathrm{ss} \mathrm{Na}^{+}$, the high intercept of the linear regression and the trend of the $\mathrm{Cl}^{-} / \mathrm{ssNa}^{+}$ratio as $\mathrm{ssNa}^{+}$flux decreases show that $\mathrm{HCl}$ is deposited in the snow layers at the same time as $\mathrm{NaCl}$. The $\mathrm{HCl}$ contribution becomes progressively more evident as distance from the sea increases (especially from $200 \mathrm{~km}$ inland). The $\mathrm{Cl}^{-} / \mathrm{ss} \mathrm{Na}^{+}$ratio reaches values more than five times higher than sea-water composition at the inland Antarctic sites, but chloride preservation is heavily controlled by the accumulation rate in the present snow acidity conditions. Sites where accumulation rate is higher than $80 \mathrm{~kg} \mathrm{~m}^{-2} \mathrm{a}^{-1}$ do not show post-depositional losses of chloride. Re-emission of $\mathrm{HCl}$ into the atmosphere from the superficial snow layers is negatively correlated to accumulation rates lower than $80 \mathrm{~kg} \mathrm{~m}^{-2} \mathrm{a}^{-1}$, as revealed by the $\mathrm{Cl}^{-} / \mathrm{ssNa}^{+}$decreasing index.

Wet deposition dominates sea-spray atmospheric scavenging both in coastal and in inland Antarctic areas. A different pattern in the scavenging rate as a function of accumulation rate is shown in NVL and Wilkes Land sectors due to the different atmospheric circulation pathways.

More knowledge of present transport, depositional and post-depositional sea-spray processes in central Antarctic regions is fundamental to the correct interpretation of paleoenvironmental and paleoclimatic records from deep ice cores.

\section{ACKNOWLEDGEMENTS}

This research was financially supported by the Ministero Istruzione, Università, Ricerca (MIUR)-PNRA program, through a cooperation agreement between the PNRA consortium and Milano-Bicocca and Venice Universities in the framework of the 'Glaciology' and 'Environmental Contamination' projects. This work is an Italian contribution to the ITASE project. It is an associate program of the 'European Project for Ice Coring in Antarctica' (EPICA), a joint European Science Foundation/European Commission (EC) scientific program, funded by the EC and by national contributions from Belgium, Denmark, France, Germany, Italy, the Netherlands, Norway, Sweden, Switzerland and the United Kingdom. This is EPICA publication No. 113.

\section{REFERENCES}

Aristarain, A.J. and R.J. Delmas. 2002. Snow chemistry measurements on James Ross Island (Antarctic Peninsula) showing seasalt aerosol modifications. Atmos. Environ., 36(4), 765-772.

Aristarain, A.J., R.J. Delmas and M. Briat. 1982. Snow chemistry on James Ross Island (Antarctic Peninsula). J. Geophys. Res., 87(C13), 11,004-11,012.

Becagli, S. and 6 others. 2003. Variability of snow depositions along the 1998/99 ITASE traverse. Terra Antarctica Reports, 8, 43-48.

Becagli, S. and 12 others. 2004. Chemical and isotopic snow variability in East Antarctica along the 2001/02 ITASE traverse. Ann. Glaciol., 39, 473-482.

Becagli, S. and 6 others. 2005. Spatial distribution of biogenic sulphur compounds (MSA, $\mathrm{nsSSO}_{4}{ }^{2-}$ ) in the northern Victoria Land-Dome C-Wilkes Land area, East Antarctica. Ann. Glaciol., 41 (see paper in this volume).

Bowen, H.J.M. 1979. Environmental chemistry of the elements. London, Academic Press.

Brimblecombe, P. 1996. Air composition and chemistry. Cambridge, Cambridge University Press.

Delmas, R.J. 1992. Environmental information from ice cores. Rev. Geophys., 30(1), 1-21.

EPICA community. 2004. Eight glacial cycles from an Antarctic ice core. Nature, 429(6992), 623-628.

Fattori, I., S. Bellandi, S. Benassai, M. Innocenti, A. Mannini and R. Udisti. 2004. Ion balances of size resolved aerosol samples from Terra Nova Bay and Dome C (Antarctica). In Colacino, M., ed. 10th Workshop Italian Research on Antarctic Atmosphere and SCAR Workshop on Oceanography, Roma, 22-24 October 2003. Bologna, SIF, 101-115. (SIF Conference Proceedings vol. 89.)

Fattori, I. and 7 others. 2005. Chemical composition and physical features of summer aerosol at Terra Nova Bay and Dome C (Antarctica). J. Environ. Monitor. 7(12), 1265-1274

Fischer, H. and D. Wagenbach. 1996. Large-scale spatial trends in recent firn chemistry along an east-west transect through central Greenland. Atmos. Environ., 30(19), 3227-3238.

Frezzotti, M. and O. Flora. 2002. Ice dynamic features and climatic surface parameters in East Antarctica from Terra Nova Bay to Talos Dome and Dome C: ITASE Italian traverses. Terra Antartica, 9(1), 47-54.

Frezzotti, M. and 12 others. 2004. New estimations of precipitation and surface sublimation in East Antarctica from snow accumulation measurements. Climate Dyn., 23(7-8), 803-813.

Gjessing, Y. 1989. Excess and deficit of sulfate in polar snow. Atmos. Environ., 23, 155-160.

Gloersen, P. and W.J. Campbell. 1991. Recent variations in Arctic and Antarctic sea-ice covers. Nature, 352(6330), 33-36.

Gragnani, R., C. Smiraglia, B. Stenni and S. Torcini. 1998. Chemical and isotopic profiles from snow pits and shallow firn cores on Campbell Glacier, northern Victoria Land, Antarctica. Ann. Glaciol., 27, 679-684.

Innocenti, M. and 6 others. 2004. Surface-distribution pattern of atmospheric aerosol particles collected in coastal and inner Antarctic sites by atomic force microscopy measurements In Colacino, M., ed. 10th Workshop Italian Research on Antarctic Atmosphere and SCAR Workshop on Oceanography, Roma, 2224 October 2003. Bologna, SIF, 87-99. (SIF Conference Proceedings vol. 89.)

Kerminen, V.M., K. Teinilä and R. Hillamo. 2000. Chemistry of seasalt particles in the summer Antarctic atmosphere. Atmos. Environ., 34(17), 2817-2825. 
Kreutz, K.J., P.A. Mayewski, I.I. Pittalwala, L.D. Meeker, M.S. Twickler and S.I. Whitlow. 2000. Sea level pressure variability in the Amundsen Sea region inferred from a West Antarctic glaciochemical record. J. Geophys. Res., 105(D3), 4047-4059.

Legrand, M. and R.J. Delmas. 1987. A 220-year continuous record of volcanic $\mathrm{H}_{2} \mathrm{SO}_{4}$ in the Antarctic ice sheet. Nature, 327(6124), 671-676.

Legrand, M.R. and R.J. Delmas. 1988. Formation of $\mathrm{HCl}$ in the Antarctic atmosphere. J. Geophys. Res., 93(D6), 7153-7168.

Magand, O., M. Frezzotti, M. Pourchet, B. Stenni, L. Genoni and M. Fily. 2004. Climate variability along latitudinal and longitudinal transects in East Antarctica. Ann. Glaciol., 39, 351-358.

Mayewski, P.A. and M. Legrand. 1990. Recent increase in nitrate concentration of Antarctic snow. Nature, 346(6281), 258-260.

Mclnnes, L.M., D.S. Covert, P.K. Quinn and M.S. Germani. 1994. Measurements of chloride depletion and sulfur enrichment in individual sea-salt particles collected from the remote boundary layer. J. Geophys. Res., 99(D4), 8257-8268.

Migliori, A., S. Becagli, S. Benassai, I. Fattori, R. Traversi and R. Udisti. 2002. Comparison between aerosol chemical composition at Terra Nova Bay and Dome C (Antarctica): preliminary results. In Colacino, M., ed. 9th Workshop Italian Research on Antarctic Atmosphere, Roma, 22-24 October 2001. Bologna, SIF, 239-252. (SIF Conference Proceedings vol. 80.)

Minikin, A., D. Wagenbach, W. Graf and J. Kipfstuhl. 1994. Spatial and seasonal variations of the snow chemistry at the central Filchner-Ronne Ice Shelf, Antarctica. Ann. Glaciol., 20, 283-290.

Mouri, H., I. Nagao, K. Okada, S. Koga and H. Tanaka. 1996. Elemental composition of individual aerosol particles collected from the coastal marine boundary layer. J. Meteorol. Soc. Jpn, 74(5), 585-591.

Mulvaney, R., G.F.J. Coulson and H.F.J. Corr. 1993. The fractionation of sea salt and acids during transport across an Antarctic ice shelf. Tellus, 45B(2), 179-187.

Murphy, D.M. and 9 others. 1998. Influence of sea-salt on aerosol radiative properties in the Southern Ocean marine boundary layer. Nature, 392(6671), 62-65.

O'Dowd, C.D. and M.H. Smith. 1993. Physicochemical properties of aerosol over the Northeast Atlantic: evidence for wind-speed related submicron sea salt production. J. Geophys. Res., 98(D1), $1137-1149$

O'Dowd, C.D., M.H. Smith, I.E. Consterdine and J.A. Lowe. 1997. Marine aerosol, sea-salt, and the marine sulphur cycle: a short review. Atmos. Environ., 31(1), 73-80.

Proposito, M. and 9 others. 2002. Chemical and isotopic snow variability along the 1998 ITASE traverse from Terra Nova Bay to Dome C, East Antarctica. Ann. Glaciol., 35, 187-194.

Rankin, A.M., V. Auld and E.W. Wolff. 2000. Frost flowers as a source of fractionated sea salt aerosol in the polar regions. Geophys. Res. Lett., 27(21), 3469-3472.
Rankin, A.M., E.W. Wolff and S. Martin. 2002. Frost flowers: implications for tropospheric chemistry and ice core interpretation. J. Geophys. Res., 107(D23), 4683. (10.1029/2002JD002492.)

Röthlisberger, R. and 6 others. 2002. Dust and sea salt variability in central East Antarctica (Dome C) over the last 45 kyrs and its implications for southern high-latitude climate. Geophys. Res. Lett., 29(20), 1963. (10.1029/2002GL015186.)

Shaw, G.E. 1989. Aerosol transport from sources to ice sheets. In Oeschger, H. and C.C. Langway, Jr, eds. The environmental record in glaciers and ice sheets. Chichester, etc., John Wiley and Sons, 13-27.

Stenni, B. and 6 others. 2000. Snow accumulation rates in northern Victoria Land, Antarctica, by firn-core analysis. J. Glaciol., 46(155), 541-552.

Traversi, R., S. Becagli, E. Castellano, O. Largiuni and R. Udisti. 2000. Stability of chemical species in firn layers from Antarctica. In Colacino, M. and G. Giovannelli, eds. 8th Workshop Italian Research on Antarctic Atmosphere, Bologna, 20-22 October 1999. Bologna, SIF, 421-443. (SIF Conference Proceedings vol. 69.)

Traversi, R. and 7 others. 2004. Spatial and temporal distribution of environmental markers from coastal to plateau areas in Antarctica by firn core chemical analysis. Int. J. Environ. Anal. Chem., 84(6-7), 457-470.

Udisti, R. 1996. Multiparametric approach for chemical dating of snow layers from Antarctica. Int. J. Environ. Anal. Chem., 63, 225-244.

Udisti, R., S. Bellandi and G. Piccardi. 1994. Analysis of snow from Antarctica: a critical approach to ion-chromatographic methods. Fresenius J. Anal. Chem., 349, 289-293.

Udisti, R., R. Traversi, S. Becagli and G. Piccardi. 1998. Spatial distribution and seasonal pattern of biogenic sulphur compounds in snow from northern Victoria Land, Antarctica. Ann. Glaciol., 27, 535-542.

Udisti, R., S. Becagli, E. Castellano, R. Traversi, S. Vermigli and G. Piccardi. 1999. Sea spray and marine biogenic seasonal contribution to snow composition at Terra Nova Bay, Antarctica. Ann. Glaciol., 29, 77-83.

Udisti, R. and 7 others. 2004a. Atmosphere-snow interaction by a comparison between aerosol and uppermost snow-layers composition at Dome C, East Antarctica. Ann Glaciol., 39, 53-61.

Udisti, R. and 9 others. 2004b. Sensitivity of chemical species to climatic changes in the last $45 \mathrm{kyr}$ as revealed by high-resolution Dome C (East Antarctica) ice-core analysis. Ann. Glaciol., 39, 457-466.

Wagenbach, D. and 7 others. 1998. Sea-salt aerosol in coastal Antarctic regions. J. Geophys. Res., 103(D9), 10,961-10,974.

Wolff, E., P. Artaxo and R. Röthlisberger. 2003. An ice core indicator of Antarctic sea ice production? Geophys. Res. Lett., 30(22), 2158. (10.1029/2003GL018454.)

Wouters, L., P. Artaxo and R. van Grieken. 1990. Laser microprobe mass analysis of individual Antarctic aerosol particles. Int. J. Environ. Anal. Chem., 38, 427-438. 